\title{
POSTEROMEDIAL RELEASE OF CONGENITAL CLUB FOOT IN CHILDREN OVER FIVE YEARS OF AGE
}

\author{
HARUYASU YAMAMOTO, TAKESHI MUNETA, TOSHIRO ISHIBASHI, KOHTARO FURUYA
}

From Tokyo Medical and Dental University, Japan

We reviewed 19 children with 24 congenital club feet at a mean of 11 years after one-stage posteromedial release at the age of five years or older (mean 6.8 years). Thirteen feet had undergone previous surgery.

Nineteen feet were functionally excellent or good, three were fair and two had required subtalar arthrodesis. Radiographs showed good alignment of the tarsal bones, although mild adduction or varus deformity remained in several feet. Deformities of the bones were more common in feet which had had previous surgery.

J Bone Joint Surg [Br] 1994; 76-B:555-8.

Received 16 August 1993; Accepted 21 December 1993

Turco (1979) reported that the best results from the surgical treatment of congenital club foot were obtained in children operated on between the ages of one and two years and that thereafter the number of excellent results diminished as the age at operation increased. DePuy and Drennan (1989) divided patients into three groups based on their age at the time of posteromedial release (early, 4 months; middle, 9 months; late, 16 months) and found that although the early group achieved better forefoot alignment, better correction of hindfoot varus and less deformity of the tarsus, there were satisfactory clinical and radiographic results in the middle and late groups as well.

We have performed one-stage posteromedial release (Turco 1971) for congenital club foot in children aged from six months to ten years and now report the results of this operation performed on children more than five years old.

H. Yamamoto, MD, PhD, Associate Professor

T. Muneta, MD, PhD, Assistant Professor

T. Ishibashi, MD, Assistant Professor

K. Furuya, MD, PhD, Professor and Chairman

Department of Orthopaedics, Tokyo Medical and Dental University, 1-545, Yushima, Bunkyo-ku, Tokyo 113, Japan.

Correspondence should be sent to Dr H. Yamamoto.

(C)1994 British Editorial Society of Bone and Joint Surgery 0301-620X/94/4805\$2.00

\section{PATIENTS AND METHODS}

From 1973 to 1990 we performed one-stage posteromedial release in 69 children with 98 congenital club feet. Of these, 23 children ( 28 club feet) were aged five years or more at the time of operation. Nineteen ( 24 club feet) have been evaluated six or more years later. The other four (4 club feet) were excluded from the study because of short follow-up. There were 14 boys and 5 girls and their average age at surgery was 6.8 years (5.2 to 9.0). The average period of follow-up was 11.0 years $(6.0$ to 18.5). Eight feet had previously undergone posterior release, two had posterior and anterior release, one had posterior and medial release, one had posteromedial and one posterior and posteromedial release. The indications for surgery were persistence of the deformity after other treatment, dorsiflexion at the ankle to less than a right angle, and a radiographic tibiocalcaneal angle, in maximum dorsiflexion, of more than $80^{\circ}$.

Operative technique. The skin was incised horizontally from the base of the first metatarsal to the lateral side of tendo Achillis which was lengthened, as were the tendons of tibialis posterior, flexor hallucis longus and flexor digitorum longus using a Z-technique. The posterior talofibular and calcaneofibular ligaments, the posterior third of the deep deltoid ligament, the superficial deltoid and the talocalcaneal interosseous ligaments, the spring ligament and the $\mathrm{Y}$ ligament were all divided. The anterior end of the calcaneus was moved laterally, the navicular anteriorly, and the head of the talus medially. In this corrected position, a Kirschner wire was inserted through the talus to the first metatarsal transfixing the talonavicular joint. An above-knee plaster cast was applied with the knee in $30^{\circ}$ flexion and the ankle in $10^{\circ}$ plantar flexion to minimise tension on the wound edges. The cast was changed once a week for six weeks and the angle of dorsiflexion was increased each time. The Kirschner wire was removed five weeks after the operation and the cast one week later. The foot was then protected with a DenisBrowne splint at night for one year and a shoe insert was used for three years (Yamamoto and Furuya 1988).

Functional assessment. The functional results were assessed using the rating system of McKay (1983), which has ten categories and a maximum score of 180 points (Table I).

Radiographic assessment. Radiographs of the foot were 
Table I. The rating system of McKay (1983)

\begin{tabular}{|c|c|}
\hline Category & $\begin{array}{l}\text { Subtract from } \\
180 \text { points }\end{array}$ \\
\hline \multicolumn{2}{|l|}{ Ankle motion } \\
\hline$>90<90$ Total & \\
\hline$>10<40$ & 0 \\
\hline$>10<30$ & -10 \\
\hline$>10<25 \quad 35$ & -20 \\
\hline$<10<25<35$ & -30 \\
\hline \multicolumn{2}{|l|}{ Angle of bimalleolar plane to } \\
\hline \multicolumn{2}{|l|}{ longitudinal plane of foot } \\
\hline & -10 \\
\hline $50^{\circ}$ to $75^{\circ}$ & -20 \\
\hline \multicolumn{2}{|l|}{ Strength of triceps surae } \\
\hline $\begin{array}{l}\text { Weight supported on toes, one foot } \\
\text { only }\end{array}$ & $\mathbf{0}$ \\
\hline Weight supported on toes, both feet & -10 \\
\hline Weight not supported on toes & -20 \\
\hline \multicolumn{2}{|l|}{ Heel } \\
\hline $0^{\circ}$ to $5^{\circ}$ valgus & $\mathbf{0}$ \\
\hline $5^{\circ}$ to $10^{\circ}$ valgus & -5 \\
\hline More than $10^{\circ}$ valgus & -10 \\
\hline Varus & -10 \\
\hline \multicolumn{2}{|l|}{ Forefoot } \\
\hline Neutral & 0 \\
\hline To $5^{\circ}$ adduction or abduction & -5 \\
\hline Over $5^{\circ}$ & -10 \\
\hline \multirow{2}{*}{\multicolumn{2}{|c|}{ Flexor hallucis longus }} \\
\hline & \\
\hline $\begin{array}{l}\text { Functional } \\
\text { Non-functional }\end{array}$ & -10 \\
\hline \multicolumn{2}{|l|}{ Ankle pain } \\
\hline Constantly disabling & -30 \\
\hline Tolerable during daily activities & -20 \\
\hline Limping at end of day & -10 \\
\hline Interferes only with running & -5 \\
\hline \multicolumn{2}{|l|}{ Subtalar pain } \\
\hline Constantly disabling & -20 \\
\hline Tolerable during daily activities & -15 \\
\hline Limping at end of day & -10 \\
\hline Interferes only with running & -5 \\
\hline Shoe wear & \\
\hline Stylish shoes foregone option & -5 \\
\hline Foot deforms shoe & -10 \\
\hline Shoes do not fit & -15 \\
\hline Sports & \\
\hline Competitive & $\mathbf{0}$ \\
\hline Non-competitive because of foot & -15 \\
\hline
\end{tabular}

taken preoperatively, one year after surgery and at the latest review. An anteroposterior radiograph was taken with the beam angled $30^{\circ}$ to the vertical while the patient stood on the cassette with the tibial tubercle directed anteriorly. From this radiograph, the talocalcaneal and the talo-first metatarsal angles were measured. The talocalcaneal and tibiocalcaneal angles were then measured on a lateral radiograph taken with the foot in maximum dorsiflexion. The lateral talo-first metatarsal angle was measured on a lateral standing radiograph. Diminished convexity of the trochlear surface of the talus was measured on the lateral radiograph and classified using the criteria of Dunn and Samuelson (1974) (Table II).

Statistical analysis was by Student's $t$-test to assess differences between the variables.
Table II. Criteria for flattening of the trochlear surface of the talus (Dunn and Samuelson 1974)

Mild flattening
$\begin{aligned} & \text { The curve of the trochlea is congruous with that of the } \\ & \text { articular surface of the tibia }\end{aligned}$
Moderate flattening $\begin{aligned} & \text { There is moderate incongruity of the articular surface } \\ & \text { The anteroposterior extent of the curve is greatly } \\ & \text { shortened, but no incongruity is present }\end{aligned}$
Severe flattening $\quad \begin{aligned} & \text { The trochlea is completely flat and there is marked } \\ & \text { incongruity between talus and tibia }\end{aligned}$

Table III. Functional results in 24 feet using the rating system of McKay (1983)

\begin{tabular}{lllll}
\hline & & $\begin{array}{l}\text { With } \\
\text { previous } \\
\text { surgery }\end{array}$ & $\begin{array}{l}\text { Without } \\
\text { previous } \\
\text { surgery }\end{array}$ & Total \\
\hline Excellent & $(175$ to 180$)$ & 5 & 10 & 15 \\
Good & $(160$ to 174$)$ & 4 & 0 & 4 \\
Fair & $(125$ to 159$)$ & 2 & 1 & 3 \\
Poor & $(90$ to 124$)$ & 0 & 0 & 0 \\
Failure & $(<90)$ & 2 & 0 & 2 \\
\hline
\end{tabular}

* see text and Table I

\section{RESULTS}

The functional results are given in Table III. Nineteen feet (79.2\%) had good or excellent results. Two feet rated as failures underwent subtalar arthrodesis and have been excluded from the results which follow. Both had had previous surgery before the posteromedial release as had two of the three feet graded as fair. No patient complained of pain during daily or strenuous activity.

The mean angle of maximum dorsiflexion was $17^{\circ}$ (8 to 25 ) and of plantar flexion, $55^{\circ}$ (45 to 60 ). The angle of the bimalleollar plane to the longitudinal plane was between $83^{\circ}$ and $90^{\circ}$ in 16 feet, between $76^{\circ}$ and $82^{\circ}$ in four, and between $50^{\circ}$ and $75^{\circ}$ in two. The valgus angle of the heels ranged from $0^{\circ}$ to $5^{\circ}$. The forefoot was in a neutral position in 16 feet, $5^{\circ}$ adducted in four feet and more than $5^{\circ}$ adducted in two feet. All patients could stand on tiptoe on one foot and the flexor hallucis longus was functional in all. Shoe wear was normal in all feet and all the patients took part in competitive sports.

The mean radiographic angles measured before operation, one year later and at last review are given in Table IV. These angles were generally better in feet which had not had previous surgery than in those which had but the differences were not significant except for the anteroposterior talocalcaneal angle $(t=-6.5, p<0.01$; Table V).

The shape of the trochlea of the talus was classified as normal in seven feet, mildly flattened in eight, moderately flattened in five and severely flattened in two. In $\mathbf{1 1}$ feet which had had previous surgery, the trochlea was classified as normal in two, mildly flattened in five, moderately flattened in two and severely flattened in two. 
Table IV. Radiographic angles in degrees (mean \pm SD) before and after surgery

\begin{tabular}{llllll}
\hline & $\begin{array}{l}\text { Anteroposterior } \\
\text { talo-first } \\
\text { metatarsal angle }\end{array}$ & $\begin{array}{l}\text { Anteroposterior } \\
\text { talocalcaneal } \\
\text { angle }\end{array}$ & $\begin{array}{l}\text { Tibiocalcaneal } \\
\text { angle }\end{array}$ & $\begin{array}{l}\text { Lateral } \\
\text { talocalcaneal } \\
\text { angle }\end{array}$ & $\begin{array}{l}\text { Lateral } \\
\text { talo-first } \\
\text { metatarsal angle }\end{array}$ \\
\hline Before surgery & $12.5 \pm 12.1$ & $21.2 \pm 9.8$ & $84.1 \pm 8.9$ & $22.9 \pm 5.8$ & $162.9 \pm 5.3$ \\
$\begin{array}{l}\text { One year after } \\
\text { surgery }\end{array}$ & $-6.6 \pm 8.8$ & $25.6 \pm 6.6$ & $63.6 \pm 7.9$ & $30.9 \pm 4.3$ & $174.4 \pm 4.4$ \\
At review & $-5.8 \pm 9.1$ & $24.8 \pm 5.3$ & $56.9 \pm 9.2$ & $34.5 \pm 5.7$ & $172.9 \pm 4.9$ \\
Normal foot & $-13.8 \pm 3.5$ & $28.6 \pm 5.0$ & $40.5 \pm 4.8$ & $37.5 \pm 6.3$ & $180.2 \pm 0.5$ \\
\hline
\end{tabular}

Table V. Radiographic angles in degrees (mean \pm SD) at review in feet with and without previous surgery

\begin{tabular}{llllll}
\hline & $\begin{array}{l}\text { Anteroposterior } \\
\text { talo-first } \\
\text { metatarsal angle }\end{array}$ & $\begin{array}{l}\text { Anteroposterior } \\
\text { talocalcaneal } \\
\text { angle }\end{array}$ & $\begin{array}{l}\text { Tibiocalcaneal } \\
\text { angle }\end{array}$ & $\begin{array}{l}\text { Lateral } \\
\text { talocalcaneal } \\
\text { angle }\end{array}$ & $\begin{array}{l}\text { Lateral } \\
\text { talo-first } \\
\text { metatarsal angle }\end{array}$ \\
\hline $\begin{array}{l}\text { With previous } \\
\text { surgery }\end{array}$ & $-3.5 \pm 7.1$ & $20.9 \pm 3.5$ & $58.4 \pm 14.8$ & $33.6 \pm 8.5$ & $174.0 \pm 4.5$ \\
$\begin{array}{l}\text { Without previous } \\
\text { surgery }\end{array}$ & $-8.4 \pm 8.8$ & $27.5 \pm 4.8$ & $55.5 \pm 8.6$ & $35.0 \pm 6.7$ & $171.7 \pm 7.4$ \\
\hline
\end{tabular}

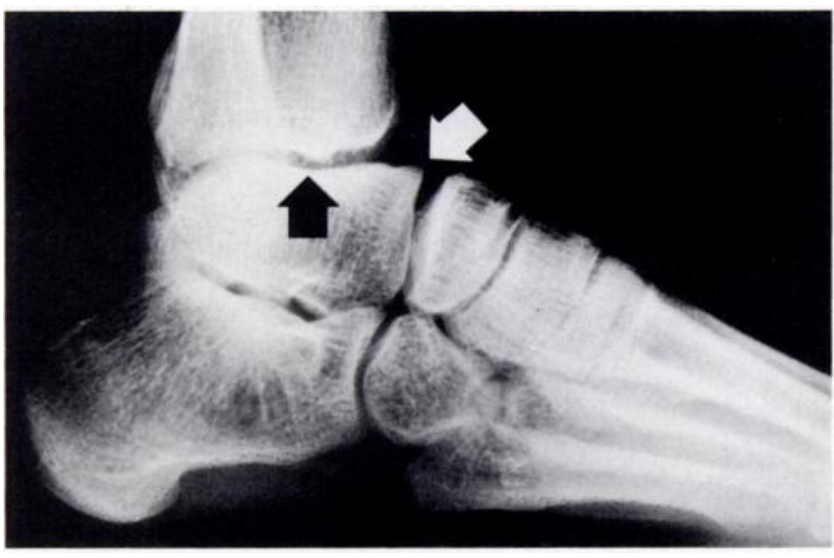

Fig. 1

Radiograph 17 years after posteromedial release for congenital club foot at the age of 6 years. There is absence of the sulcus in the neck of the talus (black arrow), a large and irregular head of the talus (white arrow) and moderate flattening of the trochlea. The foot was graded clinically as fair.

In 11 feet without previous surgery, it was classified as normal in five, mildly flattened in three and moderately flattened in three.

Absence of the normal sulcus in the neck of the talus (Fig. 1) was found in seven feet, five of which had had previous surgery. Enlargement or irregularity of the head of the talus was found in eight feet of which six had had previous surgery.

Wedging of the navicular (on the lateral radiograph as in Fig. 2) was observed in 12 feet, of which seven had had previous surgery. The mean lateral talo-first metatarsal angle of the feet with wedging of the navicular was $172.4^{\circ}$; in those without wedging it was $176.3^{\circ}$. The difference between these two groups was significant $(\mathrm{t}=-3.84, \mathrm{p}<0.05)$. Dorsal talonavicular subluxation was observed in five feet all of which had had previous surgery.

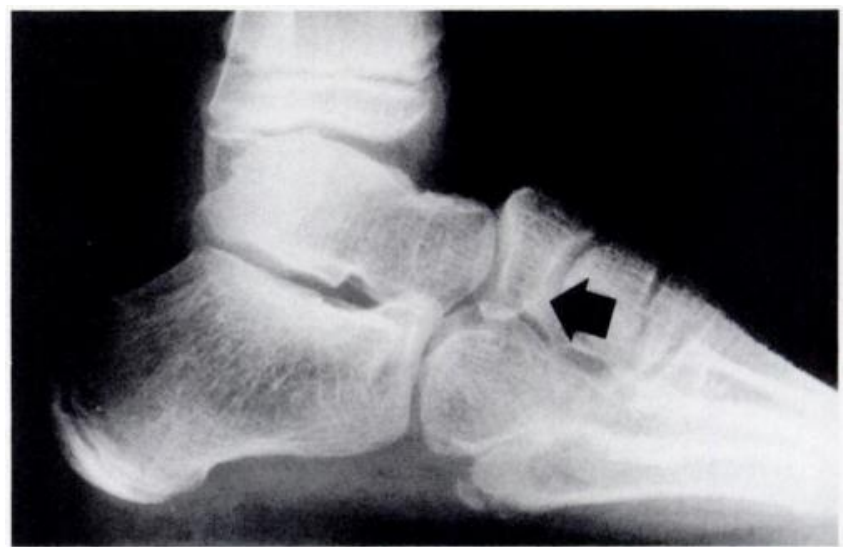

Fig. 2

Radiograph 8 years after posteromedial release for congenital club foot at the age of 7 years. There is wedging of the navicular (black arrow). The lateral talo-first metatarsal angle is $172^{\circ}$. The foot was graded clinically as good.

The mean Böhler's angle at final review was $33^{\circ}(21$ to 42 ). In 25 normal adults it was $29^{\circ}$ (18 to 40 ); the difference was not significant $(t=-3.36, p>0.05)$. The mean angle was $31^{\circ}$ in feet which had not had previous surgery and $35^{\circ}$ in feet which had.

\section{DISCUSSION}

Posteromedial release, by transecting or lengthening the contracted soft tissues, allows the tarsal bones to be realigned. In older children, or those who have had previous operations, this correction may be difficult because the bones are secondarily deformed. In our series this was the case in two feet which eventually required subtalar arthrodesis. In none of the other 22 feet, however, has any further operation been required and 19 of them were graded as functionally excellent or good. The 
deformities of these feet were in general well corrected and this was well maintained although in some mild adduction or varus deformity remained.

Excellent or good results were obtained in $91 \%$ of feet which had not had previous surgery and in $69 \%$ of feet which had. The tarsal angles were also better in the former than in the latter, although the differences were not significant except for the anteroposterior talocalcaneal angle.

Ponseti et al (1981) reported that in many club feet which had undergone previous treatment the talus and calcaneus were small, the trochlea of the talus had diminished convexity, the head of the talus was flattened and the navicular wedge-shaped. Miller and Bernstein (1986) examined the radiological appearances of 24 corrected club feet and found wedging of the navicular in $67 \%$, dorsal talonavicular subluxation in $54 \%$, flattening of the talus in $83 \%$, and an irregular head of the talus in $38 \%$. We found wedging of the navicular in $55 \%$, dorsal talonavicular subluxation in $23 \%$, flattening of the talus in $68 \%$, and an irregular head of the talus in $36 \%$. These deformities were all mild when the age of the children at the time of surgery is considered.

In our patients flattening of the trochlea of the talus, although it was seen in $68 \%$ of feet, was usually mild and most feet had a good range of motion at the ankle. Turco

\section{REFERENCES}

DePuy J, Drennan JC. Correction of idiopathic clubfoot: a comparison of results of early versus delayed posteromedial release.J Pediatr Orthop 1989; 9:44-8.

Dunn HK, Samuelson KM. Flat top talus: a long term report of twenty club feet. J Bone Joint Surg [Am] 1974; 56-A:57-62.

McKay DW. New concept of and approach to clubfoot treatment: section III evaluation and results. J Pediatr Orthop 1983; 3:141-8.

Miller JH, Bernstein SM. The roentgenographic appearance of the 'corrected clubfoot'. Foot \& Ankle 1986; 6:177-83.

Ponseti IV, El-Khoury GY, Ippolito E, Weinstein SL. A radiographic study of skeletal deformities in treated clubfeet. Clin Orthop 1981; 160:30-42. and Spinella (1982) stated that even if it was considerably deformed, the talus had the capacity to remodel after restoration of normal tarsal relationships.

Miller and Bernstein (1986) suggested that wedging of the navicular might be due to compression of its inferior part between the cuneiform bones and the talus by forced dorsiflexion of the foot during correction of the deformity by serial casting. We found this deformity in feet with a small lateral talo-first metatarsal angle and speculate that it arose not only from compression during casting, but also from incomplete correction of the original cavus deformity.

Böhler's angle is a measure of the development of the calcaneum (Schlafly et al 1985); an increased angle implies a poorly developed calcaneal tuberosity, resulting from a weak gastrocnemius due to excessive elongation of tendo Achillis. In our patients the angle was similar to that of normal adults, a result which fits with the observation that most patients had normal power of plantar flexion.

The follow-up period of our patients is still short and most of them are still in their twenties. A further review will be required to evaluate the final outcome.

No benefits in any form have been received or will be received from a commercial party related directly or indirectly to the subject of this article.
Schlafly B, Butler JE, Siff SJ, Criswell AR, Cain TE. The appearance of the tarsal navicular after posteromedial release for clubfoot. Foot \& Ankle 1985; 5:222-37.

Turco VJ. Surgical correction of the resistant club foot: one-stage posteromedial release with internal fixation. J Bone Joint Surg [Am] 1971; 53-A:477-97.

Turco VJ. Resistant congenital club foot - one stage posteromedial release with internal fixation: a follow-up report of a fifteen-year experience. J Bone Joint Surg [Am] 1979; 61-A:805-14.

Turco VJ, Spinella AJ. Current management of clubfoot. In: AAOS Instructional Course Lectures. St Louis, etc: CV Mosby Co, 1982; 31:218-34.

Yamamoto H, Furuya K. One-stage posteromedial release of congenital clubfoot. J Pediatr Orthop 1988; 8:590-5. 